\title{
Supply chain integration, organizational performance and balanced scorecard: \\ An empirical study of the banking sector \\ in Jordan
}

\author{
Miklós Pakurár \\ Institute of Applied Informatics and Logistics, \\ Faculty of Economics and Business, University of Debrecen, \\ Debrecen, Hungary \\ pakurar.miklos@econ.unideb.hu
}

\section{Hossam Haddad}

Institute of Applied Informatics and Logistics,

Faculty of Economics and Business,

University of Debrecen, Debrecen,

Hungary

hossam.haddad@econ.unideb.hu

\section{József Popp}

Institute of Sectoral Economics and Methodology,

Faculty of Economics and Business,

University of Debrecen, Debrecen,

Hungary

popp.jozsef@econ.unideb.hu (corresponding author)

Tehmina Khan

RMIT University,

Melbourne, Australia

tehmina.khan@rmit.edu.au

\section{Judit Oláh}

Institute of Applied Informatics and Logistics,

Faculty of Economics and Business,

University of Debrecen, Debrecen,

Hungary

olah.judit@econ.unideb.hu 
Abstract. This paper examines the impact of supply chain integration on organizational performance in Jordanian banking sector. Supply chain integration is divided into two categories: customer and internal integration. Organizational performance comprises of the following perspectives: customers, internal processes, organizational capacity and stewardship. The results demonstrate that supply chain integration is significantly related to organizational performance. Evidence of the improved organisational performance is also provided in the feedback from some of the surveyed banks. Internal integration impacts all four organizational performance dimensions; however, customer integration has impact only on customer perspective. The results suggest that improved customer involvement could help develop the banks' performance. Primary data was collected by using a questionnaire at Jordanian banks. The research model was tested using data from the sample $(n=112)$ of nine banks in Jordan. The data was analysed by means of exploratory factor analysis. The results of the multiple regression analysis show that supply chain integration effects significantly organizational performance.

Keywords: supply chain integration, customer integration, internal integration, organizational performance, banks.

JEL Classification: G21, L26, O16

\section{INTRODUCTION}

In the 21 st century organizations find themselves working in a rapidly changing environment which is characterized by vicious competition, globalization, rising expectations and demands of various customers, emphasis on corporate social responsibility (Sroka \& Szanto, 2018; Stonkute et al., 2018; Shpak et al., 2018) and the emergence of performance related issues. In the light of this environmental reality, traditional management strategies and practices have become rather ineffective and insufficient to outperform competitors and create more value (Teece, 2007; Grobler \& De Bruyn, 2018). Organizational performance is considered as the most significant issue for all organizations. Moreover, organizations are seeking to specify which factors should influence their organizational performance in order to enhance performance. Meyer et al., (2016) and Meyer \& Meyer (2017) opine that through creation of an enabling business environment and by identifying the barriers to growth in time, organizations can obtain higher performance.

It is vital to have a performance measurement system in any organization because it plays a substantial role in developing strategic plans and evaluating the achievement of organizational objectives. Usually traditional performance measurement is based on the management/cost accounting system, which is no longer feasible in current business environment due to its focus on the short-term. Furthermore, shortcomings of the traditional performance measures include weak links with strategic objectives, lack of operational details, quality relations and customer loyalty. Kaplan \& Norton (2001) have suggested the use of the balanced scorecard (BSC) as a methodology to measure organizational performance. The balanced scorecard combines traditional financial measures with non-financial measures to provide managers with more significant and relevant information about organizational performance.

Supply chain integration has emerged as one of the most valuable sources of enhancing organizational performance (Flynn et al., 2010). Supply chain integration includes two main dimensions: 
customer integration and internal integration that provide organizations with a competitive advantage at the market.

Studies conducted in different countries have found a strong direct link between supply chain integration and organizational performance (Droge et al., 2004; Stank et al., 2001). Limited studies have been conducted to investigate the impact of supply chain integration on organizational performance in the emerging markets' banking sector.

The aim in this article is to consider the impact of supply chain integration on organisational performance as identified through the balanced scorecard. The main research question is: What is the impact of supply chain integration on organizational performance in Jordanian banking sector? Four research sub questions have been formulated:

To what extent are supply chain integration dimensions developed in Jordanian banking sector?

What is the state of Jordanian banking performance according to the balanced scorecard methodology?

What is the impact of supply chain integration dimensions on organizational performance in Jordanian banking sector?

Which of the two supply chain integration dimensions has the most significant impact on organizational performance of Jordanian banking sector?

Banking sectors play a critical role in creating and adding value to economies and societies. Therefore, continuous improvement of organizational performance of this sector has always been a priority. In addition, there has been an increasing emphasis placed on measuring the organizational performance of banks using both financial and non-financial indicators. Thus, the importance of this research is considered as one of a limited number of studies that have attempted to measure the organizational performance of Jordanian banking sector according to the BSC methodology.

\section{LITERATURE REVIEW}

\subsection{Supply chain integration}

The intention of supply chain management is to eliminate communication barriers and remove redundancies throughout coordinating, monitoring and controlling processes in the organization. Supply chain integration attempts to establish the inter links between each component of the chain, to help better decision making and to allow all components of the chain to cooperate in a more flexible way. These steps produce supply chain visibility and recognition of bottlenecks (Chadha \& Gagandeep, 2013; Pakurar et al., 2019).

Researchers argue that a variety of personal co-operations support the improvement of production and service potentials (Rosenzweig et al., 2003; Swink et al., 2007; Narasimhan \& Kim, 2002; Qia et al., 2017). Integration often associates with process progress achievements, collective planning movements, and enhancement of communications. The mix and interaction of expertise, operations, and organizational relationships are the capabilities of the firm, and it is hard to replicate (Davies \& Joglekar, 2013).

Problem recognition and disentanglement over and above creation and utilization of opportunities take place as integrative actions generating path for learning and growing. Aforementioned schemes are motivators, inducing cooperation between the firm and its supply chain members. Organizational integration efforts open opportunities for synergistic applications of new knowledge (Narasimhan et al., 2010). Integration is associated with advancement in product development, together with additional improvements of organizational performance (Gerwin \& Barrowman, 2002; Swink \& Calantone, 2004). 
A completely integrated supply chain behaves as a single vertically integrated unit, enabling information exchange, enhancing performance throughout the chain (Novak \& Stern, 2008; Kot et al., 2018a, b). Strategic SCM integration integrates customer and supplier information into the enterprise throughout cross business communications and in-house cross-functional teams (Flynn et al., 2010; Lee et al., 2007; Droge et al., 2004; Narasimhan \& Kim, 2002; Giménez \& Ventura, 2005; Abdallah et al., 2014; Frohlich \& Westbrook, 2001; Rosenzweig et al., 2003; Vickery et al., 2003).

Requirements of customers go beyond the border of the department frequently and involve adjustments for different situation between teams of functions. People, working in encouraging organizations where a variety of skills needed and they are engaged in cross-functional activities are probably more successful at listening the voice of the customer. In addition, employees being proficient to build relationships between functional groups of the enterprise may be the initiators of improving connections with external partners (Koufteros et al., 2014). Employees involved in many relationships inhouse have an effect on the external integration and they are members of a network that spans through enterprises (Tushman \& Scanlan, 1981).

Supply chain integration boosts efficiency by decreasing the risk of dealing with suppliers and customers and increasing the efficiency of management of business processes (Towill et al., 2002; Dikos \& Spyropoulou, 2013). Implementers of supply chain efficiency are pleased with increased financial performance (Davies \& Joglekar, 2013). Implementers of supply chain efficiency look forward to financial performance cost reduction and better customer awareness (Fisher, 1997). According to Kulatilaka \& Trigeorgis' (2004) research superior efficiency enables organizations to improve their capability to handle uncertainty in order to decrease risk (Kulatilaka \& Trigeorgis, 2004).

Integration with external associates requires major resources, both tangible and intangible. Integration of external partners involves the acceptance of up-to-date technology and active participation of SC partners in innovations. Likewise, SC partners should allocate their expertise through customers and organizations (Koufteros et al., 2014).

Customer integration can be seen as a method of collecting and understanding customer needs and wants, and division of mutual knowledge (Swink et al., 2007). If design-integrative efforts are not based on the customer's demand the design team may create a product that seam good but it is unproductive externally.

Ataseven \& Nairb (2017) found that customer integration has a positive relation with financial performance, however it is not enough to develop higher business performance abilities to perform. Good relationship with customers is important and to know their special needs however if the products and processes are not performed to satisfy the needs of customers, the value of good relationship is limited.

Complex organizations are composed of many varied, interconnected parts. Complexity hinders the capability of organization members to identify and take action in relation to core importance. Unusually the silo effect and narrow-mindedness is possible contributors. Managers have to solve problems arousing from complex structures like building cooperation, thinking together and taking decisions with SC partners (Ataseven \& Nairb, 2017; Koufteros et al., 2007).

In a more horizontal structure of an organization information can flow easily from the bottom to the top in the enterprise. This structure enables employees to build personal relationships with each other which can solve problems in groups. Flatness increases the number of stakeholders at every level; when a problem is jointly solved, the employees in charge are able to interact directly (Kostova \& Roth, 2003).

Skilled and practised employees are able to cooperate with in a crossfunctional way in the company. Having been involved in the work of different departments of the company, managers can develop internal integration of the organization. A manager cooperating with different people of different departments can solve problems more easily internally and externally (Adler \& Kwon, 2002). Internal 
integration is an initial step toward achieving supply chain integration (Swink et al., 2005). It is very important for managers to know which factors affect an organization's performance in order to take suitable steps and to use resources in an efficient and effective way (Mafini \& Pooe, 2013). Supply chain managers take a comprehensive perspective of relevant activities and seek to develop integration of operations to understand the voice of the customer (Tan et al., 2002).

Ibrahim et al. (2018) states that microfinance institutions required to be stable financially based on the organization's features and their characteristics. There is a positive and significant relationship between the charged interest rate and the presence in the market on the financial performance of microfinance institutions. Moreover, credit union and non-bank financial firms as well perform financially better than their competitors. Therefore, a high-interest rate could develop organizations' financial self-sufficiency and comply with their social promise.

In order to prevent customer defection, companies make proactively barriers by switching cost related to the customer loyalty and organization performance. Ngo \& Pavelková (2017) shows that there is a positive relationship between switching costs and customer loyalty.

\subsection{Supply chain in banking}

Generally, banks are in the focal point of economic activities of all supply chains. Finance supply chains and their role in physical and financial supply chain integration is crucial. Silvestro \& Lustrato (2014) found that the banks can improve supply chain (SC) integration, and assist the SC partners to make better physical and financial SC integration. Financial service organizations as SC members are general to all supply chains, independent of the type of products and services streaming down the supply chain and independent of the type of the organization being engaged in the SC. Banks facilitate supply chain integration with harmonization, collaboration, information sharing, and information visibility.

In Jordan there are three types of banks: commercial banks, Islamic banks and foreign banks: sixteen, four and nine banks respectively. Islamic banking represents the system of natural processes or business transactions that take place according to the values and principles of Islam called "Sharia". An Islamic bank cannot support business activities that are against the Islamic law (Central Bank of Jordan, 2018). All three types of Jordanian banks are involved in this study.

Internal integration in the banking sector is the flow of information between the units of the bank. For example, the senior management of the bank comprises a board of directors headed by the chairman, and committees to help other members to take the right decision (Central Bank of Jordan, 2018). The committees consist of a credit committee, corporate strategy committee, nomination and remuneration committee, a corporate governance committee, audit committee, and risk management committee. These committees have direct links with the board and the chairman as well. The chief executive officer supervises all the departments in the bank business (credit, corporate and institutional banking, treasury and consumer banking). The support consists of the following departments: economic research, operations, information technology, procurement, real estate, construction management, project management offices, human resources, branding, and finance. All of these departments work together internally to achieve a common purpose.

\subsection{Aligning activities with balance scorecard}

Kaplan - Norton (1992) first introduced the balanced scorecard (BSC) as a performance dimension system that gives a holistic view of the organizations financial and non-financial performance, hence drawing management attention beyond traditional accounting measures. The balanced scorecard provides quite a few benefits to the organization in creating strategy and achieving the organizations goals. It 
provides a comprehensive view of the tangible and intangible assets of an organization. Unlike performance measures which only provide financial information, the balanced scorecard simultaneously works as a "performance management process and strategy implementation tool". BSC helps align performance measures with the mission and strategy of the organization; while at the same time establishing a system of nonstop feedback where all members of the organization are aware of their involvement with the firm's business processes and understand how those said processes can be improved (Rao \& Sreelakshmi, 2017).

The BSC provides employees with a complete framework that translates an organization's vision and strategy into a logical set of performance measures (Van \& Staden, 2009; Dobrovič et al., 2018). The BSC includes not only historical (lag) performance measures (such as financial targets) but also leading indicators such as customer fulfilment and expectations, and learning opportunities. The BSC is a strategic management tool that provides the manager with a clear and brief picture of the organizations health and progress in attaining the goals of the organization (Kaplan \& Norton, 1992).

Van \& Staden (2009) defines the BSC as a carefully selected set of measures resulting from an organizations strategy. The measures selected for the BSC, correspond to a tool for leaders to use in communication to employees and external stakeholders. The balanced score card measured areas are: finance, customer, processes, and abilities (Kaplan \& Norton, 1996; Mafini \& Pooe, 2013; Norreklit, 2000). Financial perspective usually uses return on investment (ROI), return on equity (ROE) and operating income.

\subsection{Linking supply chain integration with organizational performance}

Supply chain managers take a comprehensive perspective of relevant actions and seek to improve achievement by coordinating their activities to satisfy customers (Tan et al., 2002, Yousuf et al., 2019). As the integration of SC increases the performance of an enterprise improves (Frohlich \& Westbrook, 2001). A development in supply chain integration generates advantages for SC members throughout the chain improving their competitiveness (Power, 2005; Maestrini et al., 2016).

McAdam \& McCormack (2001) suggest that businesses are gaining competitive advantage by increasing the effectiveness of their global supply chains. A conceptual model of an integrated business process, resulting from the case study, is obtainable, which highlights the significance of communication between processes and associates in the supply chain (Chadha \& Gagandeep, 2013).

Frohlich \& Westbrook (2001) have developed a level for measuring supply chain integration. They have suggested that customer integration strategies are a diverse "arc of integration". The widest level of arc of integration with customers has strongest relationship with performance development (Chadha \& Gagandeep, 2013). Integration can be seen as attitude of participants internally and externally that strongly connected to the performance of a business (Schoenherr \& Swink, 2012; Taylor \& Helfat, 2009; Teixeira et al., 2012).

\section{RESEARCH METHOD}

The population of this research consists of Jordanian banks. The number of these banks is 27 including commercial, Islamic and foreign banks. The unit of analysis comprises all managerial and nonmanagerial levels (top, middle, low and executives). The authors of this study distributed 200 questionnaires, 33 of those were unreturned and 55 questionnaires were eliminated due to missing data or unsuitability for analysis, thus resulting in 112 questionnaires being valid for further analysis. Based on this, the response rate was $56 \%$ and nine banks from the total of 27 used effectively the balanced scorecard. 
Descriptive statistics and a correlation analysis were performed (Sekaran \& Bougie, 2009; Sekaran \& Bougie, 2013; Keller, 2011) to characterise the samples and explain the impact of supply chain integration dimensions on the organizational performance.

Exploratory factor analysis was performed to test the supply chain integration and balanced scorecard constructs. Kaiser's measure of 0.50 for SCI items, and 0.741 for BSC items, and Bartlett's test of Sphericity Chi-square $\chi^{2}$ was used to support results of Kaiser $\chi^{2}$ and were statistically significant $(\mathrm{p} \leq$ $0.001)$ for "SCI" and "BSC". Thus suggesting that factor analysis is appropriate for analysing the data in both instances. Using Cronbach's alpha test it was found that the internal consistency values reflect high internal consistency and high reliability.

Supply chain integration and organisational performance shown in Figure 1.

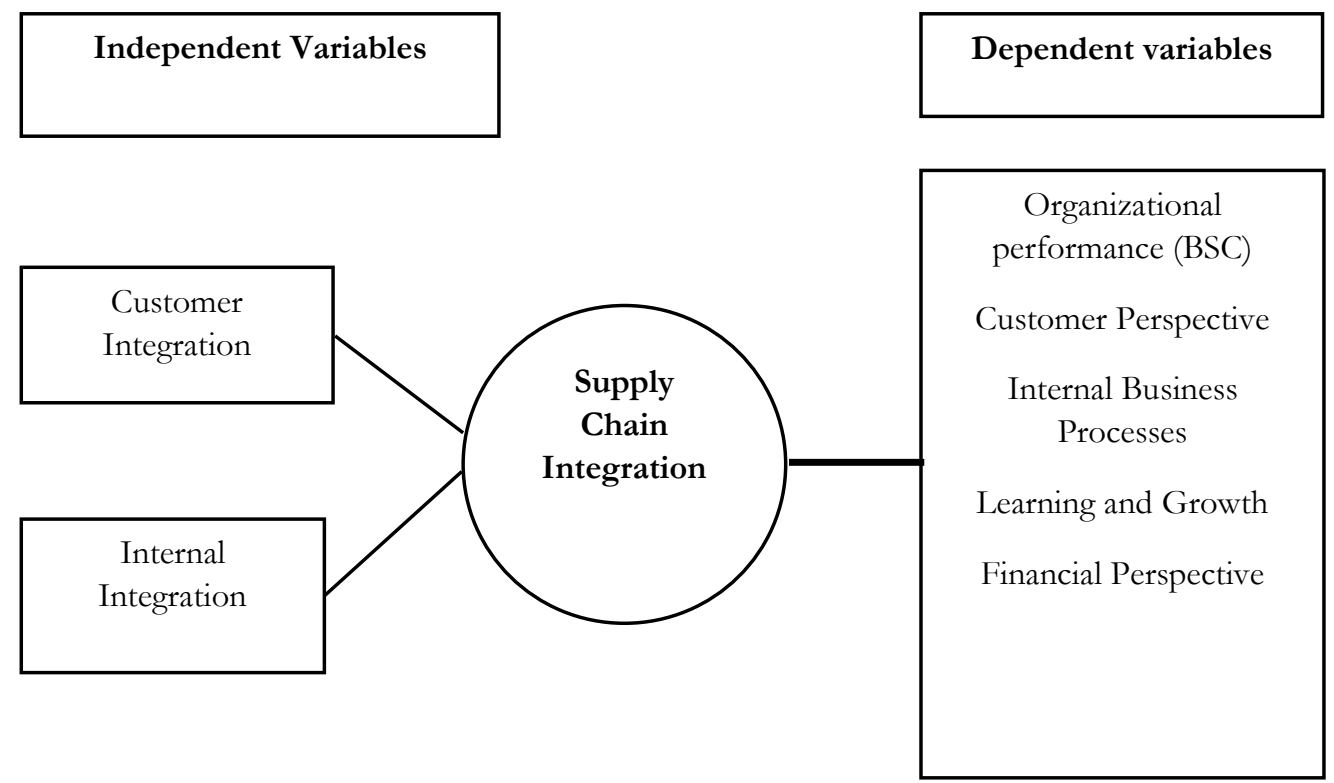

Figure 1. Supply chain integration and organisational performance.

Source: Author's own research, 2018.

The model of supply chain integration (Figure 1) is based on the publications of Flynn et al. (2010); Lee et al. (2007); Droge et al. (2004); Narasimhan \& Kim (2002); Giménez \& Ventura, (2005); Abdallah et al. (2014); Kaplan \& Norton (2001); Mafini \& Pooe (2013).

The following hypotheses have been constructed:

H1: There is an impact of supply chain integration (comprising of customer and internal integration) on the organizational performance in the Jordanian banking sector.

- H1.1 There is a significant impact of supply chain integration on the customer perspective as captured in the balance score card in the Jordanian banking sector.

- H1.2 There is a significant impact of supply chain integration on the internal business processes as captured in the balance score card in the Jordanian banking sector.

- H1.3 There is a significant impact of supply chain integration on learning and growth as captured in the balance score card in the Jordanian banking sector.

- H1.4 There is a significant impact of supply chain integration on the financial perspective as captured in the balance score card in the Jordanian banking sector. 
To measure these dimensions a survey questionnaire was constructed with 33 questions based on the following factors.

\section{Customer' integration}

1. Evaluation of customers' complaints.

2. Reaction to customers' opinion on quality.

3. Measurement and evaluation of customers' satisfaction.

4. Determination of forthcoming demand of customers.

5. Motivation of customers to express problems.

6. Maintaining fairness with customers.

\section{Internal integration}

7. The functions in our firm work well together.

8. The functions in our firm cooperate to solve conflicts between them, when they arise.

9. The marketing and finance areas know a great deal about the types and forms of services to be provided.

10. Our company's functions coordinate their activities to achieve objectives

11. All departments in the company are working interactively with each other.

\section{Customer perspective}

12. Most customers are satisfied with our products.

13. Our organization collects information concerning customers' needs and requirements.

14. Feedback from customers is taken seriously.

15. The organization is keen to produce excellent products in order to guarantee customers' satisfaction.

16. The organization is keen on building a positive image in the minds of its customers.

\section{Internal business processes}

17. Quality skills and competences are available in our organization.

18. Cross-functional communication flows easily throughout the organization

19. The level of wastage in the organization is low.

20. Our products are always conformed to specifications.

21. We have excellent on time delivery performance.

22. The organization continuously improves its internal processes.

\section{Learning and growth}

23. Innovation is encouraged in our organization.

24. I have the opportunity to participate in training and development programs.

25. I have many opportunities to make independent decisions.

26. Our organization encourages employees' suggestions.

27. Our organization trains and develops employees in order to improve the organization performance.

28. Our organization rotates employees between departments in order to enrich and enhance their skills, knowledge and abilities.

\section{Financial perspective}

29. The organization's profits have consistently increased over the last three years

30. The organization's profits have increased at a higher rate compared with competitors.

31. In our organization, financial resources are managed effectively.

32. The organization is always able to meet its financial goals.

33. Financial control measures are effective and well placed. 


\section{Independent Variables}

Supply chain integration: Integrated system that consist of number of advantages and characteristics that is shaped by relying on a number of departments within an organization. Considering customers and internal departments whether inside or outside the organization in order to provide valuable services to the customers (11 questions).

Customer integration: Responding to customers need and wants through long term relationships management with the purpose to improve customer satisfaction, complaints and feedback, customer satisfaction and customer expectation and the sense of fair-lay with customers (6 questions).

Internal integration: The organizations ability to structure their own organizational strategies according to their collaborative practices and processes with the purpose to satisfy customer needs and wants and to achieve competitive consistent integration within an organization and achieve competitive advantage, interactive functions among department, conflict solvation and information sharing (5 questions).

\section{Dependent Variables}

Balance scorecard: A performance management system that measures the organizational performance from financial and non-financial perspectives represented by financial, customer, internal business processes and learning and growth perspectives (13 questions).

Customer perspective: This includes customer satisfaction; customer retention and market share in target markets (5 questions).

Internal business processes: Refers to all internal processes, the goals achievement, employees' qualification, communication networks, specification confirmation, time delivery performance and internal processes improvement (5 questions).

Learning and growth: Refers to how the organization manages to create continuous growth and improvement through people, systems and organizational procedures, innovation encouragement, training and gained performance, and the dependency on decision making and employees rotation (6 questions).

Financial perspective: Refers to the organization's profit measured subjectively through profit in recent years, profit increment ratio, the effectiveness of financial management, financial goals achievement and the effectiveness of financial measures (4 questions).

The research design for this research was quantitative, descriptive, and co-relational. A quantitative research method was applied based on quantifiable data to obtain objectivity of the research by using a well-developed questionnaire. Objectivity could be achieved by means of numbers and statistics. Descriptive research design was applied to provide a summary of the data and describe the characteristics of the variables of interest (Sekaran \& Bougie, 2013). A correlation design was performed to measure the strength of the investigated relationship between variables (Keller, 2011) to analyse the impact of supply chain integration dimensions (customer integration and internal integration) on the organizational performance dimensions by using the BSC perspectives (customer perspective, internal business processes, learning and growth and financial perspective) of the Jordanian banking sector.

\section{EMPIRICAL RESULTS}

After an interview conducted with Dr. Adli Kandah, the general manager of the Association of Banks in Jordan, several questions raised can be answered based on the real situation in Jordanian banks. The money and information are the most important parts of the supply chain in the banks. The suppliers in the Jordanian banking sector can be the depositors and lenders. Customers in the banks can be individuals, institutions (small and medium enterprises and government), banks, service providers, and 
others. The interaction between the external supply chain (customer and suppliers) and internal integration improve the performance and customer satisfaction, which have an important impact on the overall supply chain. The Jordanian banking sector aligns the cash and information flow of the supply chain. There are tiers of the suppliers and customers, for example, the banks can take loans from foreign or local banks under the license granted to it by the central bank of Jordan. Central bank plays an essential role by drawing the policies, bylaws, and internal regulations. The central bank is the last lord of the stumbling banks.

The findings have confirmed the important effect of supply chain integration on the customer perspective. This result is consistent with previous literature investigating the relationship of supply chain integration on the organizational performance.

Checking the assumptions of regression analysis (multicollinearity) encountering a statistical phenomenon regarding a multiple regression model in which two or more independent variables are highly correlated is called "multicollinearity". This phenomenon may become a problem if the purpose of the research is to estimate the individual regression coefficients and the relative importance for each. There are many statistical tools used to detect multicollinearity but in this research the variance inflation factor (VIF) is checked. VIF related measures indicate the degree to which one independent variable is explained by the other independent variable, VIF is a measure of how much the variance of the estimated regression coefficients are inflated because of the collinearity, the greater the VIF than 10 then there is a serious problem (Bowerman \& O'Connell, 1990), therefore, the rule of thumb, multicollinearity becomes a cause for concern, when VIF is larger than 10 (Hair et al., 1998).

The main hypothesis (H1) of this study is that there is an impact of supply chain integration (comprising of customer and internal integration) on the organizational performance in the Jordanian banking sector. The results are presented in Table 1.

Table 1

Variance Inflation Factor

\begin{tabular}{|c|c|}
\hline Variables & VIF \\
\hline Customer Integration & 1.257 \\
\hline Internal Integration & 1.257 \\
\hline
\end{tabular}

Variance Inflation Factor "VIF" $\geq 2.5$

Source: Author's own research, 2018.

It is noticed from the Table 1 that the "VIF" value for each of the independent variables is less than 10, the results of the collinearity statistics of "VIF" indicate that there is no multicollinearity within the data, which in turn strengthen the model of the research by avoiding the problem of having interchangeable " $\beta$ " values between independent variables, and reducing the bias resulting from type II error.

The multiple regression analysis suggests that there is a strong positive correlation $(r=0.676)$ between supply chain integration (customer integration and internal integration) and organizational performance (Table 2), and $45.6 \%$ of the amount of variation in organizational performance can be attributed to supply chain integration of customer integration and internal integration. Internal integration $(\beta=0.540)$ has a significantly stronger effect on the organizational performance then customer integration $(\beta=0.230)$. 
SCI on organizational performance

\begin{tabular}{|l|c|c|}
\hline \multicolumn{1}{|c|}{ Variables } & Coefficients & p-value \\
\hline (Constant) & 1.717 & 0.000 \\
\hline Customer integration & $0.230(\beta)$ & 0.004 \\
\hline Internal integration & $0.540(\beta)$ & 0.000 \\
\hline $\mathrm{r}$ & 0.676 & - \\
\hline $\mathrm{r}^{2}$ & 0.456 & - \\
\hline Adj. $\mathrm{r}^{2}$ & 0.446 & - \\
\hline $\mathrm{F}$ & 45.749 & - \\
\hline
\end{tabular}

Source: Author's own research, 2018.

4.1. Supply chain integration and the performance in four critical areas: customers, processes, learning and growing and finances

Impact of supply chain integration on the performance of banks in four critical areas is discussed by testing our sub-hypotheses from H1.1 to H1.4 (Table 3).

In relation to the first sub-hypothesis (H1.1) a strong positive correlation $(\mathrm{r}=0.648)$ was found between supply chain integration (customer integration and internal integration) and customer perspective as represented in the balance scorecard. The $(\mathrm{R})$ value is a measure of how well the model predicts the observed data. Supply chain integration (customer integration and internal integration) can be explained in $42.1 \%$ of the variation in customer perspective. There is a statistically significant effect of supply chain integration (customer integration and internal integration) on customer perspective. The multiple regression analysis result is that customer integration has the stronger effect on customer perspective then internal integration, $\beta=0.420$ and $\beta=0.340$ respectively.

Table 3

Multiple linear regression of supply chain integration on the critical areas of the balanced scorecard

\begin{tabular}{|l|c|c|c|c|c|c|c|c|}
\hline \multirow{2}{*}{ Variables } & \multicolumn{2}{|c|}{$\begin{array}{c}\text { Customer } \\
\text { perspective }\end{array}$} & \multicolumn{2}{c|}{$\begin{array}{c}\text { Internal business } \\
\text { processes }\end{array}$} & \multicolumn{2}{c|}{$\begin{array}{c}\text { Learning and } \\
\text { growth }\end{array}$} & \multicolumn{2}{c|}{$\begin{array}{c}\text { Financial } \\
\text { perspective }\end{array}$} \\
\cline { 2 - 9 } & Coefficients & $\begin{array}{c}\text { p- } \\
\text { value }\end{array}$ & Coefficients & $\begin{array}{c}\text { p- } \\
\text { value }\end{array}$ & Coefficients & $\begin{array}{c}\text { p- } \\
\text { value }\end{array}$ & $\begin{array}{c}\text { Coefficients } \\
\text { p- } \\
\text { value }\end{array}$ \\
\hline Constant & 1.622 & 0.000 & 1.539 & 0.000 & 1.545 & 0.000 & 2.162 & 0.000 \\
\hline $\begin{array}{l}\text { Customer } \\
\text { integration }\end{array}$ & $0.420(\beta)$ & 0.000 & $0.111(\beta)$ & 0.155 & $0.170(\beta)$ & 0.069 & $0.078(\beta)$ & 0.424 \\
\hline $\begin{array}{l}\text { Internal } \\
\text { integration }\end{array}$ & $0.340(\beta)$ & 0.000 & $0.633(\beta)$ & 0.000 & $0.413(\beta)$ & 0.000 & $0.375(\beta)$ & 0.000 \\
\hline $\mathrm{r}$ & 0.648 & - & 0.691 & - & 0.513 & - & 0.416 & - \\
\hline $\mathrm{r}^{2}$ & 0.421 & - & 0.477 & - & 0.263 & - & 0.173 & - \\
\hline Adj. ${ }^{2}$ & 0.410 & - & 0.468 & - & 0.249 & - & 0.158 & - \\
\hline F & 39.551 & - & 49.750 & - & 19.440 & - & 11.419 & - \\
\hline
\end{tabular}

Source: Author's own research, 2018.

In relation to Hypothesis H1.2 it is found that there is an impact of supply chain integration on the internal business processes (Table 3). A strong positive correlation is found between supply chain integration and internal business processes. The value of $\mathrm{r}^{2}=0.477$ indicates that supply chain 
integration of customer integration and internal integration can explain $47.7 \%$ of the variation and change in internal business processes. There is a statistically significant effect of supply chain integration on internal business processes. Internal integration has a strong effect $(\beta=0.633)$ on the internal business processes, the effect of customer integration is not significant at $\alpha \leq 0.05$ level.

Testing hypothesis H1.3, it was found that there is a statistically significant impact of supply chain integration on learning and growth as represented in the balance score card in the banking sector (Table 3). There is a strong positive correlation between supply chain integration and learning and growth and supply chain integration can explain $26.3 \%$ of the variation in organizational performance. The $\beta$ coefficient of internal integration was statistically significant and relatively high (0.413), however the $\beta$ coefficient of customer integration was statistically insignificant and low (0.170). Therefore only the internal integration has an effect on learning and growth.

For the last hypothesis statement (H1.4) it is found that there is an impact of supply chain integration on the financial perspective as represented in the Balance score card in the banking sector (Table 3). The multiple correlation coefficient $(\mathrm{r}=0.416)$ indicates that there is a strong positive correlation between supply chain integration and financial perspective. Supply chain integration of customer integration and internal integration can explain $17.3 \%$ of the variation and change in financial perspective. There is a statistically significant effect of supply chain integration on financial perspective. The $\beta$ coefficient of the internal integration was statistically significant and relatively high (0.375). The $\beta$ coefficient of customer integration was statistically insignificant and low (0.078).

\section{DISCUSSION}

Supply chain integration is seen as a way to develop and maintain a competitive advantage, with respect to the role of intra-organizational relationship and interactions among individuals and groups to facilitate, enhance, and leverage this process with the aim to reach competitiveness. The findings emerging from hypotheses testing have proven that there is a statistically significant impact of the supply chain integration on the organizational performance. Similar results have been found in earlier studies (Kannan \& Tan, 2010; Wong et al., 2011; Prajogo \& Olhager, 2012; Richey et al., 2009; Schoenherr \& Swink, 2012; Vijayasarathy, 2010; Aryee et al., 2008; Li et al., 2009; Stank et al., 2001b; Childerhouse \& Towill, 2003; Giménez - Ventura, 2005; Koufteros et al., 2005; Droge et al., 2004; Wang et al., 2006; Vickery et al., 2003; Hertz, 2001; Swink et al., 2007; Salvador et al., 2001; Narasimhan \& Kim, 2002; Narasimhan \& Das, 2001; Wong et al., 2011; Prajogo \& Olhager, 2012; Kovács et al., 2017). The positive impacts of supply chain integration are also demonstrated in the feedback received from the organisations regarding the implementation of supply chain integration.

Integrating with customers enables the organization to identify customer needs and wants and helps recognize market gaps and changes in the external environment. Hence the organization generates new strategies to meet changes and to empower customers and finally participate in achieving organizational goals. Furthermore, integrating with customers supports organizations to differentiate profitable customers from regular ones, which in return facilitates the achievement of financial goals (Ramdas \& Spekman, 2000).

Internal integration plays a corner stone in enhancing the communication networks between employees and managerial levels, giving employees the sense of freedom to share different perspectives, opinions and knowledge. Removing boundaries between departments encourages employees to suggest and share new ideas. In regards to business processes, it is reflected in the efficiency and effectiveness of the work, decreasing work pressure and increasing employee's loyalty and motivation. 
The findings have confirmed the important effect of supply chain integration on customer perspective, consistent with previous research (Schoenherr \& Swink, 2012; Aryee et al., 2008; Stank et al., 2001; Koufteros et al., 2005; Vickery et al., 2003, Kovacova, 2018). One of the main purposes of customer integration is to specifically identify customer needs and wants. The organization will not identify these needs unless they carefully respond to customer complaints and take into consideration customers' feedback this will provide the organization with indicators of changes in customers' demands and external environment, which is considered as valuable information in order to meet customers' needs and wants.

The new product-service development heavily depends on the information gained from collaborative practices with customers, regarding their opinion of a product or service. The research and development department restructures and redesigns the product-service in order to meet or exceed customer expectations and to cover their needs and wants according to the gathered information from customers. In addition, the organization will formulate and generate new marketing and pricing strategies that meet customer's expectations in regards to a product-service and to gain customer satisfaction and to empower customers. The organization should aim to achieve the organizational and market goals that are consistent with the changes of customers' needs, wants, trends and changes in the external environment. The findings confirmed the effect of supply chain integration on the internal business processes.

Supply chain integration plays a dominant role in removing boundaries between employees themselves through decreasing formality in a two-communication strategy (employees and managers). High internal integration inside the organization affects the process integration, which will be reflected on the overall integration process, such as the production time. Cost and waste will be decreased and the time schedule and delivery performance will be enhanced. Moreover, when there is a high level of internal integration the organization will be more capable of conducting changes in the internal environment in order to follow the changes in the external environment, which will be reflected in better and more interactive functioning of the departments. Implementing internal process improvements may provide the organizations with contemporary competitive advantage internally and externally.

The effect of supply chain integration on learning and growth was confirmed by the study and the results are consistent with previous research (Oláh et al., 2017; Oláh et al., 2018; Prajogo \& Olhager, 2012; Schoenherr \& Swink, 2012; Vijayasarathy, 2010; Vickery et al., 2003; Hertz, 2001). Whenever there is high internal integration, the formality within the organization decreases, especially within the executive levels and their immediate managerial levels. Hence, managers will be able to explore and point out the employee related issues and weaknesses. They train and develop employees to solve current problems, and to motivate talented employees to innovate. This is reflected in each employee's performance and then on the overall performance of the organization. In addition, higher level of integration facilitates in a more extensive flow of information within organizations supply chain and its departments.

The study confirmed the effect of supply chain integration on the financial perspective similarly to the literature in the field (Wong et al., 2011; Schoenherr \& Swink, 2012; Childerhouse \& Towill, 2003; Droge et al., 2004; Wang et al., 2006; Vickery et al., 2003). Internal integration plays a big role in new strategies development that also addresses the financial goals. The financial goals are developed in accordance with the internal processes and integration such as the interactive collaborative processes and practices among organization departments that will be positively reflected in performance, production and waste reduction. Overall an increase in supply chain integration will lead to customer satisfaction, which will lead to an increase in market share and eventually an increase in profit. 


\section{CONCLUSION}

This research tested a theoretical framework that examined the impact of the supply chain integration which includes customer integration and internal integration on the organizational performance using the balanced scorecard methodology that related to four aspects of a business: financial, customer, internal processes and organizational capacity, with respect to the Jordanian banking sector. Some banks from the Jordanian banking sector have provided evidence that supply chain integration has had a positive impact on organisational performance.

The results of data analysis show that higher supply chain integration has an increasing performance impact for the Jordanian banking sector. This indicates an acknowledgement of the importance of the role played by customer integration and internal integration to maximize organizational performance which leads ultimately to building competitive advantage.

Although supply chain integration has a significant and positive impact on organizational performance this research found that the more dominant dimension is internal integration. The internal integration positively effects all four critical areas of BSC. Customer integration effects only customer perspective from the balance scorecard critical areas.

It can be concluded, that the bank managers' opinion is that banking skills and know-how are more important than having and building a good relationship with the customer. The fact that the bank managers do not think that customer integration has important impact on banking processes, learning and grows, and financial performance means that they do not utilize fully the voice of the customer to improve these areas. The main recommendation in this paper is that improved customer involvement can help to develop the banks' performance in all areas. For better understanding of customer integration and customer perspective, it is advisable for future similar studies to undertake analyses of customer perspectives to understand their expectations of banking services.

There were some limitations to this research. First, the administrative position of the authorsposed a constraint because it was difficult to gain access to managers or higher level representatives from the administration. Second, since the research used closed-ended questionnaire items as the primary data collection instrument, respondents were not able to provide in-depth explanations concerning the impact of supply chain integration on organizational performance using balance scorecard methodology. Finally, the target population of the research consisted only of the Jordanian banks, thus, the findings of this research can not be generalized beyond the Jordanian Banking Sector without further research.

\section{REFERENCES}

Abdallah A., Obeidat B., \& Aqqada N. (2014). The Impact of Supply Chain Management Practices on Supply Chain Performance in Jordan: The Moderating Effect of Competitive Intensity. International Business Research, 7(3), 1327. doi: https://doi.org/10.5539/ibr.v7n3p13

Adler P. S., \& Kwon S. W. S. (2002). Social capital: Prospects for a new concept. Academy of Management Review, 27(1), 17-40. doi: https://doi.org/10.5465/amr.2002.5922314

Aryee C., Naim M. M., \& Lalwani C. (2008). Supply chain integration using a maturity scale. Journal of Manufacturing Technology Management, 19(5), 559-575. doi: https://doi.org/10.1108/17410380810877258

Ataseven C., \& Nairb A. (2017). Assessment of supply chain integration and performance relationships: A metaanalytic investigation of the literature, International Journal of Production Economics, 185, 252-265. doi: https://doi.org/10.1016/j.ijpe.2017.01.007

Central Bank of Jordan (2018). Financial and Banking Sector in Jordan, [online]. http://www. cbj.gov.jo/pages. php? menu_id $=12 \&$ local_typc $=0 \&$ local_id $=0 \&$ local_CBJ.

Chadha S., \& Gagandeep (2013). Empowering Quality Management Systems through Supply Chain Management Integration: A Survey of Select Hospitals in Chandigarh, Mohali and Panchkula. Journal of Supply Chain 
Management, 1(2), 44-53. http://eds.b.ebscohost.com/eds/detail/detail?vid=0\&sid=e75c3d57-b16a-4746-ad5a$535608826 \mathrm{~cd} 5 \% 40 \mathrm{pdc}-\mathrm{v}-$ sessmgr02\&bdata=JkF1dGhUeXBIPWlwLHVpZCZzaXRIPWVkcy1saXZl\#AN=89521615\&db=buh

Childerhouse P., \& Towill D. R. (2003). Simplified material flow holds the key to supply chain integration. Omega, 31(1), 17-27. doi: https://doi.org/10.1016/S0305-0483(02)00062-2

Davies, J., \& Joglekar N. (2013). Supply Chain Integration, Product Modularity, and Market Valuation: Evidence from the Solar Energy Industry. Production and Operations Management Society, 22, 1494-1508. doi: https://doi.org/10.1111/poms.12052

Dikos G., \& Spyropoulou S. (2013). Supply chain optimization and planning in Heracles General Cement Company. Interfaces, 43(4), 297-312. doi: https://doi.org/10.1287/inte.2013.0689

Dobrovič, J., Urbański, M., Gallo, P., Benková, E., \& Čabinová, V. (2018). Balanced scorecard concept as a tool of strategic management and its usage in the construction industry. Polish Journal of Management Studies, 18 (2), 5972. doi: https://doi.org.10.17512/pjms.2018.18.2.05

Droge C., Jayaram J., \& Vickery S. K. (2004). The Effects of internal versus external integration practices on timebased performance and overall firm performance. Journal of Operations Management, 22(6), 557-573. doi: https://doi.org/10.1016/j.jom.2004.08.001

Fisher M. L. (1997). What is right supply chain for your product? Harvard Business Review, 75, 105-106.

Flynn B., Huo B., \& Zhao X. (2010). The Impact of supply chain integration on performance: a contingency and configuration approach. Journal of Operations Management, 28(1), 58-71. doi: https://doi.org/10.1016/j.jom.2009.06.001

Frohlich T. M., \& Westbrook R. (2001). Arcs of Integration: An International Study of Supply Chain Strategies. Journal of Operations Management, 19(1), 185-200. https://doi.org/10.1016/S0272-6963(00)00055-3

Gerwin D., \& Barrowman N. J. (2002). An evaluation of research on integrated product development. Management Science, 48(7), 938-953. doi: https:// doi.org/10.1287/mnsc.48.7.938.2818

Giménez C., \& Ventura E. (2005). Logistics-production, logistics marketing and external integration: their impact on performance, International Journal of Operations and Production Management, 25(1), 20-38. doi: https://doi.org/10.1108/01443570510572222

Grobler, P.A., \& De Bruyn, A.J. (2018). High-performance work practices (HPWPs) in determining success of South African companies: fact or fiction?. Journal of Contemporary Management, 15(1), 288-313.

Hertz S. (2001). Dynamics of alliances in highly integrated supply chain networks. International Journal of Logistics, 4(2), 237-256. doi: https://doi.org/10.1080/13675560110060009

Johnson M. E. (2006). Supply chain management: Technology, globalization, and policy at a crossroads. Interfaces, 36(3), 191-193. doi: https://doi.org/10.1287/inte.1060.0214

Kannan V. R., \& Tan G. K. (2010). Supply chain integration: cluster analysis of the impact of span of integration. Supply Chain Management: International Journal, 5(3), 207-215. doi: https://doi.org/10.1108/13598541011039965

Kaplan R. S., \& D. P. Norton. (1992). The Balanced Scorecard - Measures that Drive Performance. Harvard Business Review, January-February, 71-79.

Kaplan R. S., \& Norton D. P. (1996). The Balanced Scorecard. Boston: Harvard Business School Press.

Kaplan S., \& Norton P. (2001). Transforming the balanced scorecard from performance measurement to strategic management: Part I. Accounting Horizons, 15(1), 87-104. doi: https://doi.org/10.2308/acch.2001.15.1.87

Keller R. A. (2011). A phylogenetic analysis of ant morphology (Hymenoptera: Formicidae) with special reference to the poneromorph subfamilies. Bulletin of the American Museum of Natural History, 3(5), 1-90. doi: https://doi.org/10.1206/355.1

Kostova, T., \& Roth K. (2003). Social capital in multinational corporations and a micro-macromodel of its formation. Academy of Management Review, 28(2), 297-317. doi: https://doi.org/10.5465/amr.2003.9416356

Kot, S., Onyusheva, I., \& Grondys, K. (2018a). Supply Chain Management in SMEs: Evidence from Poland and Kazakhstan. Engineering Management in Production and Services, 10 (3), 23-36. doi: https://doi.org/10.2478/emj2018-

Kot, S., Goldbach, I. R., \& Ślusarczyk, B. (2018b). Supply chain management in SMEs - Polish and Romanian 
approach. Economics and Sociology, 11(4), 142-156. doi:10.14254/2071-789X.2018/11-4/9

Koufteros X. A., Nahm A., Cheng T. C. E., \& Lai K. H. (2007). An empirical assessment of anomological network of organizational design constructs: From culture to structure to pull production to performance. International Journal of Production Economics, 106(2), 468-491. doi: https://doi.org/10.1016/i.iipe.2006.08.001

Koufteros X., Peng D. X., Lu G., \& Peters R. (2014). The Impact of Organizational Structure on Internal and External Integration an Empirical, Cross-Regional Assessment. Journal of Organization Design, 3(2), 1-17. https://ssrn.com/abstract $=2461591$

Koufteros X., Vonderembse M. \& Jayaram J. (2005). Internal and external integration for product development: the contingency effects of uncertainty, equivocality, and platform strategy. Decision Sciences, 36(1), 97-133. doi: https://doi.org/10.1111/j.1540-5915.2005.00067.x

Kovács, G., \& Kot, S. (2017). Economic and social effects of novel supply chain concepts and virtual enterprises. Journal of International Studies, 10(1), 237-254. doi:10.14254/2071-8330.2017/10-1/17

Kovacova M., Kliestik T., Kubala P., Valaskova K., Radišić M., \&Borocki J. 2018. Bankruptcy models: verifying their validity as a predictor of corporate failure. Polish Journal of Management Studies 18(1): 167-179. doi: https://doi.org/10.17512/pjms.2018.18.1.13

Kulatilaka N., \& Trigeorgis L. (2004). The general flexibility to switch: Real options revisited. E. Schwartz, L. Trigeorgis, eds. Real Options and Investment under Uncertainty: Classical Readings, Recent Contributions, Cambridge: MIT Press.

Lee W. G., Kwon G. W., \& Severance D. (2007). Relationship between supply chain performance and degree of linkage among supplier, internal integration and customer. Supply Chain Management Journal, 12, 444-452. doi: https://doi.org/10.1108/13598540710826371

Li G., Yang H., Sun L., \& Sohal S. A. (2009). The Impact of IT implementation on supply chain integration and performance. International Journal of Production Economics, 120(1), 125-138. doi: https://doi.org/10.1016/i.ijpe.2008.07.017

Maestrini V., Luzzini D., Maccarrone P., \& Caniato F. (2016). Supply Chain Performance Measurement Systems: A Systematic Review and Research Agenda, International Journal of Production Economics, 183, 299-315. doi: https://doi.org/10.1016/j.ijpe.2016.11.005

Mafini C., \& Pooe D. R. I. (2013). Performance Measurement in a South African Government Social Services Department: A Balanced Scorecard Approach. Mediterranean Journal of Social Science, 4(14), 23-36. doi: https://doi.org/10.5901/mjss.2013.v4n14p23

McAdam R., \& McCormack D. (2001). Integrating Business Processes for Global Alignment and Supply Chain Management. Business Process Management Journal, 7(2), 113-130. doi: https://doi.org/10.1108/14637150110389696

Meyer, D.F., \& Meyer, N. (2017). Management of small and medium enterprise (SME) development: An analysis of stumbling blocks in a developing region. Polish Journal of Management Studies, 16(1), 127-141. doi: https://doi.org/ 10.17512/pjms.2017.16.1.11

Meyer, D.F., Meyer, N., \& Neethling, J.R. (2016). Perceptions of business owners on service delivery and the creation of an enabling environment by local government. Administratio Publica, 24(3), 52-73.

Narasimhan R., \& Das A. (2001). The imact of purchasing integration and practices on manufacturing performance. Journal of Operations Management, 19(5), 593-609. doi: https://doi.org/10.1016/S0272-6963(01)00055-9

Narasimhan R., \& Kim S. (2002). Effect of supply chain integration on the relationship between diversification and performance: evidence from Japanese and Korean firms. Journal of Operations Management, 20(3), 303-323. doi: https://doi.org/10.1016/S0272-6963(02)00008-6

Narasimhan R., Swink, M., \& Viswanathan S. (2010). On Decisions for Integration Implementation: An Examination of Complementarities Between Product-Process Technology Integration and Supply Chain Integration. Decision Sciences Institute, 41(2), 355-372. doi: https://doi.org/10.1111/j.1540-5915.2010.00267.x

Norreklit H. (2000). The balance on the balanced scorecard - a critical analysis of some of its assumptions. Management Accounting Research, 11(1), 65-88. doi: https://doi.org/10.1006/mare.1999.0121

Novak S., \& Stern S. (2008). How does outsourcing affect performance dynamics? Evidence from the automobile industry. Management Science, 54(12), 1963-1979. doi: https://doi.org/10.1287/mnsc.1080.0922 
Oláh J., Karmazin Gy., Máté D., Grabara J. K., \& Popp J. (2017). The effect of acquisition moves on income, pre-tax profits and future strategy of logistics firms, Journal of International Studies, 10(4), 233-245. doi: https://doi.org/10.14254/2071-8330.2017/10-4/18

Oláh J., Sadaf R., Máté D., \& Popp J. (2018). The influence of the management success factors of logistics service providers on firms' competitiveness. Polish Journal of Management Studies, 17(1), 175-193. https://doi.org/10.17512/pjms.2018.17.1.15

Pakurár M., Haddad H., Nagy J., Popp J., \& Oláh J. (2019). The Impact of Supply Chain Integration and Internal Control on Financial Performance in the Jordanian Banking Sector. Sustainability, 11(5), 1248, 1-20. doi: https://doi.org/10.3390/su11051248

Power D., (2005). Supply chain management integration and implementation: A literature review. Supply Chain Management International Journal, 10(4), 252-263. doi: https:// doi.org/10.1108/13598540510612721

Prajogo D., \& Olhager J. (2012). Supply chain integration and performance: the effects of long-term relationships, information technology and sharing, and logistics integration. International Journal of Production Economics, 135(1), 514-522. doi: https://doi.org/10.1016/j.ijpe.2011.09.001

Qia Y., Huob B., Wangc Z., \& Yeung H. Y. J. (2017). The impact of operations and supply chain strategies on integration and performance. International Journal of Production Economics, 185, 162-174. doi: https://doi.org/10.1016/j.ijpe.2016.12.028

Ramdas K., \& Spekman, R. E. (2000). Chain or shackles: understanding what drives supply-chain performance. Interfaces, 30(4), 3-21. doi: https://doi.org/10.1287/inte.30.4.3.11644

Rao D. S., \& Sreelakshmi G. (2017). Balanced Scorecard-Strategy Mapping Tool: A Case Study (February 2017). Asian Journal of Applied Science and Technology, 1(1), 117-121, https://ssrn.com/abstract=2928828

Richey G. R., Chen H., Upreti R., Fawcett, S., \& Adams, G. F. (2009). The Moderating role of barriers on the relationship between drivers to supply chain integration and firm performance. International Journal of Physical Distribution and Logistics Management, 39(10), 826-840. doi: https://doi.org/10.1108/09600030911011432

Rosenzweig E. D., Roth A. V., \& Dean J. W. (2003). The influence of an integration strategy on competitive capabilities and business performance: An exploratory study of consumer products manufacturers. Journal of Operations Management, 21(4), 437-456. doi: https://doi.org/10.1016/S0272-6963(03)00037-8

Salvador F., Forza C., Rungtusanatham M., \& Choi T. Y. (2001). Supply chain interactions and time-related performances: an operations management perspective. International Journal of Operations and Production Management, 21(4), 461-475. doi: https://doi.org/10.1108/01443570110381372

Schoenherr T., \& Swink M. L. (2012). Revisiting the arcs of integration: Cross-validations and extensions. Journal of Operations Management, 30(1-2), 99-115. doi: https://doi.org/10.1016/i.jom.2011.09.001

Sekaran U., \& Bougie R. (2009). Research Methods for Business: A Skill-Building Approach. 5th Edition, John Wiley and Sons Inc: Hoboken.

Sekaran U., \& Bougie R. (2013). Research Methods for Business: A Skill Building Approach. 5th Edition. Wiley: New Jersey

Silvestro R., \& Lustrato P. (2014). Integrating financial and physical supply chains: the role of banks in enabling supply chain integration, International Journal of Operations - Production Management, 34(3), 298-324. doi: http://dx.doi.org/10.1108/IJOPM-04-2012-0131

Shpak N., Stanasiuk N.S., Hlushko O.V., \& Sroka W. (2018). Assessment of the social and labor components of industrial potential in the context of Corporate Social Responsibility. Polish Journal of Management Studies, 17(1), 209-220. doi: https://doi.org/10.17512/pjms.2018.17.1.17

Sroka W., \& Szanto R. (2018). CSR and business ethics in controversial sectors: analysis of research results, Journal of Entrepreneurship, Management and Innovation. 14(3), 111-126. doi: https://doi.org/10.7341/20181435

Stank T. P., Keller S. A., \& Closs D. J. (2001a). Performance benefits of supply chain logistical integration. Transportation Journal, 41(2/3), 32-46. https:/ /www.jstor.org/stable/20713491

Stank T. P., Keller S. B. \& Daugherty P. J. (2001b). Supply chain collaboration logistical service performance. Journal of Business Logistics, 22(1), 29-48. doi: https://doi.org/10.1002/j.2158-1592.2001.tb00158.x

Stonkute E., Vveinhardt J., \& Sroka W. (2018). Training the CSR sensitive mind-set: the integration of CSR into the training of business administration professionals, Sustainability, 10, 754, doi: 
https://doi.org/10.3390/su10030754

Swink M., \& Calantone R. (2004). Design-manufacturing integration as a mediator of antecedents to new product design quality. IEEE Transactions on Engineering Management, 51(4), 472-482. doi: https://doi.org/10.1109/TEM.2004.835088

Swink M., Narasimhan R., \& Kim S. W. (2005). Manufacturing practices and strategy integration: Effects on cost efficiency, flexibility, and market-based performance. Decision Sciences, 36(3), 427-457. doi: https://doi.org/10.1111/j.1540-5414.2005.00079.x

Swink M., Narasimhan R., \& Wang C. (2007). Managing beyond the factory walls: Effects of four types of strategic integration on manufacturing plant performance. Journal of Operations Management, 25(1), 148-164. doi: https://doi.org/10.1016/j.jom.2006.02.006

Taylor A., \& Helfat C. E. (2009). Organizational linkages for surviving technological change: Complementary assets, middle management, and ambidexterity. Organization Science, 20, 718-739. doi: https://doi.org/10.1287/orsc.1090.0429

Tan K. C., Lyman S. B., \& Wisner D. (2002). Supply chain management: A strategic perspective. International Journal of Operation and Production Management, 22(6), 614-631. doi: https://doi.org/10.1108/01443570210427659

Teece J. (2007). Explicating dynamic capabilities: the nature and micro-foundations of (sustainable) enterprise performance. Strategic Management Journal, 28(13), 1319-1350. doi: https://doi.org/10.1002/smj.640

Teixeira. R., Koufteros X., \& Peng D. X. (2012). Organizational structure, integration, and manufacturing performance: A conceptual model and propositions. Journal of Operations and Supply Chain Management, 5(1), 7081. doi: http://dx.doi.org/10.12660/joscmv5n1p70-81

Towill D. R., Childerhouse P., \& Disney, S. M. (2002). Integrating the automotive supply chain. International Journal Physical Distance of Logistics Management, 32(1/2), 79-95. doi: https://doi.org/10.1108/09600030210421705

Tushman M., \& Scanlan, T. (1981). Boundary Spanning Individuals: Their Role in Information Transfer and Their Antecedents. The Academy of Management Journal, 24(2), 289-305. https://doi.org/10.5465/255842

Van-Staden A. (2009). The Balanced Scorecard as performance measurement and personal development tool in a steel organization. North West University, Vaderbulpark. Campus Faculty of Business and Management Science.

Vickery S. K., Jayaram J., Droge, C., \& Calantone R. (2003). The effects of an integrative supply chain strategy on customer service and financial performance: An analysis of direct versus indirect relationships. Journal of Operations Management, 21(5), 523-539. doi: https://doi.org/10.1016/i.jom.2003.02.002

Vijayasarathy L. R. (2010). Supply integration: an investigation of its multi-dimensionality and relational antecedents. International Journal of Production Economics, 124(2), 489-505. https:// doi.org/10.1016/j.ijpe.2010.01.010

Wang E. T., Tai J. C., \& Wei H. L. (2006). A virtual integration theory of improved supply chain performance. Journal of Management Information Systems, 23(2), 41-64. doi: https://doi.org/10.2753/MIS0742-1222230203

Wong C. Y., Boonitt S., \& Wong C. W. Y. (2011). The contingency effects of environmental uncertainty on the relationship between supply chain integration and operational performance. Journal of Operations Management, 9(6), 604-615. doi: https://doi.org/10.1016/i.jom.2011.01.003

Yousuf, A., Haddad, H., Pakurár, M., Kozlovskyi, S., \& Felföldi, J. (2019). The Effect of Operational Flexibility on Performance: A Field Study on Small and Medium-sized Industrial Companies in Jordan. Montenegrin Journal of Economics, 15(1), 47-60. doi: http:/ /dx.doi.org/10.14254/1800-5845/2019.15-1.4 